\title{
Anomalous heat and mass budget of Glaciar Zongo, Bolivia, during the 1997/98 El Niño year
}

\author{
P. Wagnon, ${ }^{1 *}$ P. Ribstein, ${ }^{2}$ B. Francou, ${ }^{3}$ J. E. Sigart ${ }^{2}$ \\ ${ }^{1}$ CEMAGREF, BP 76, 38402 Saint-Martin-d'Hères Cedex, France \\ ${ }^{2}$ L'Institut de Recherche pour le Développement, UMR Sisyphe, 75252 Paris Cedex 05, France \\ ${ }^{3}$ IRD, Ap. Post. 17.11.6596, Quito, Ecuador
}

\begin{abstract}
During El Niño-Southern Oscillation (ENSO) warm events, outer tropics glaciers usually experience a deficit of precipitation, an increase of air temperature and a strongly negative mass balance. At Glaciar Zongo, Bolivia, this was particularly striking during the vigorous 1997/98 El Niño event, one of the strongest of the century, and which resulted in an annual depth of runoff two-thirds higher than normal. We compare the energy balance on the glacier between two contrasting cycles, 1996/97 (La Niña year) and $1997 / 98$ (El Niño year). Due to a $1.3^{\circ} \mathrm{C}$ increase of annual mean air temperature, the sensible-heat flux slightly increases from 6.1 to $9.8 \mathrm{~W} \mathrm{~m}^{-2}$. During the El Niño year, sublimation is reduced, leaving more energy for melting $\left(\mathrm{LE}=-18.1 \mathrm{~W} \mathrm{~m}{ }^{-2}\right.$ in 1996/97 and $\mathrm{LE}=-11.6 \mathrm{~W} \mathrm{~m}^{-2}$ in 1997/98). The main factor responsible for the dramatic increase in melting is the net all-wave radiation, which is three times higher in 1997/98 than in 1996/ 97 (48.7 and $15.8 \mathrm{~W} \mathrm{~m}^{-2}$, respectively). This sharp increase of net all-wave radiation is related to the decrease of albedo due to the precipitation deficit.
\end{abstract}

\section{INTRODUCTION}

The sensitivity of mountain glaciers to climatic changes is widely recognized (e.g. Kuhn, 1981; Oerlemans and Fortuin, 1992; Oerlemans, 1994; Diaz and Graham, 1996; Hodge and others, 1998; Oerlemans and others, 1998). Because of the peculiar climatic conditions prevailing in the tropics (permanent melting in the ablation zone of glaciers throughout the year due to steady air temperature and constant incident solar radiation), tropical glaciers are particularly sensitive climatic indicators (Hastenrath and Kruss, 1992; Hastenrath and Ames, 1995; Wagnon and others, 1999). Several tropical ice cores have been analyzed to define the major precipitation trends and to quantify the difference between the Last Glacial Stage and the Holocene (Thompson and others, 1995, 1998). With these cores, some attempts have also been made to characterize the impact of El Niño-Southern Oscillation (ENSO) warm events on the local climate (Thompson and others, 1984). Nevertheless, in order to understand the relation between ENSO warm events and tropical glacier melting, a physical approach of the glacier response to the variations of the meteorological variables is still needed (Vuille and others, 1998; Vuille, 1999). For this purpose, we compare computed energy fluxes on Glaciar Zongo, Bolivia $\left(16^{\circ} \mathrm{S}, 68^{\circ} \mathrm{W}\right)$, during one of the strongest ENSO warm events of the century (1997/98), with the energy-balance cycle of the previous La Niña year. Energy fluxes are computed from measurements at an energy-balance automatic weather station (AWS) located at $5150 \mathrm{~m}$ a.s.l. near the equilibrium-

\footnotetext{
* Present address: Laboratoire de Glaciologie et Géophysique de l'Environnement du CNRS, 54 rue Molière, BP96, 38402 Saint-Martin-d'Hères Cedex, France.
}

line altitude (ELA), and are verified using mass-balance measurements. The El Niño year 1997/98 was marked by an exceptionally increased ablation on Glaciar Zongo due to increases of each flux of the energy balance. This comparison between the two contrasted cycles 1996/97 and 1997/98 highlights which terms of the energy balance are responsible for the dramatic melting of tropical glaciers observed during ENSO warm events.

\section{LOGATION AND MEASUREMENT PROGRAM}

Glaciar Zongo is located in the Cordillera Real, Bolivia $\left(16^{\circ} 15^{\prime} \mathrm{S}, 68^{\circ} 10^{\prime} \mathrm{W}\right)$, approximately $30 \mathrm{~km}$ north of $\mathrm{La} \mathrm{Paz}$, and forms part of the Huayna Potosi Massif. The glacier extends from 6000 to $4900 \mathrm{~m}$ a.s.l. and covers $77 \%$ of a southeast-facing hydrological catchment $\left(3 \mathrm{~km}^{2}\right)$, above the main hydrometric station located at $4830 \mathrm{~m}$ a.s.l. Precipitation is collected by a network of rain gauges distributed at various altitudes around the glacier (Fig. 1).

Since September 1991, the Glaciar Zongo mass balance has been measured using a stake and pit network extending from $5750 \mathrm{~m}$ a.s.l. to the terminus at $4890 \mathrm{~m}$ a.s.l. (Fig. 1). This network includes 12-16 stakes distributed on the lower part between 5200 and $4890 \mathrm{~m}$ a.s.l., and 2-6 snow pits dug between 5550 and $5750 \mathrm{~m}$ a.s.l. While all the stakes are surveyed every month, only the area lying between 5030 and $5170 \mathrm{~m}$ a.s.l. contains sufficient stakes $(4-10)$ to present continuous monthly data for the whole 84 month period (except August and September 1992). This selected area is located on the regular and flat part of the glacier which comprises $47 \%$ of the area lying below the average equilibrium-line altitude (ELA) (average ELA $=5250 \mathrm{~m}$ a.s.l.).

The glaciological stakes, hydrometric station, rain 


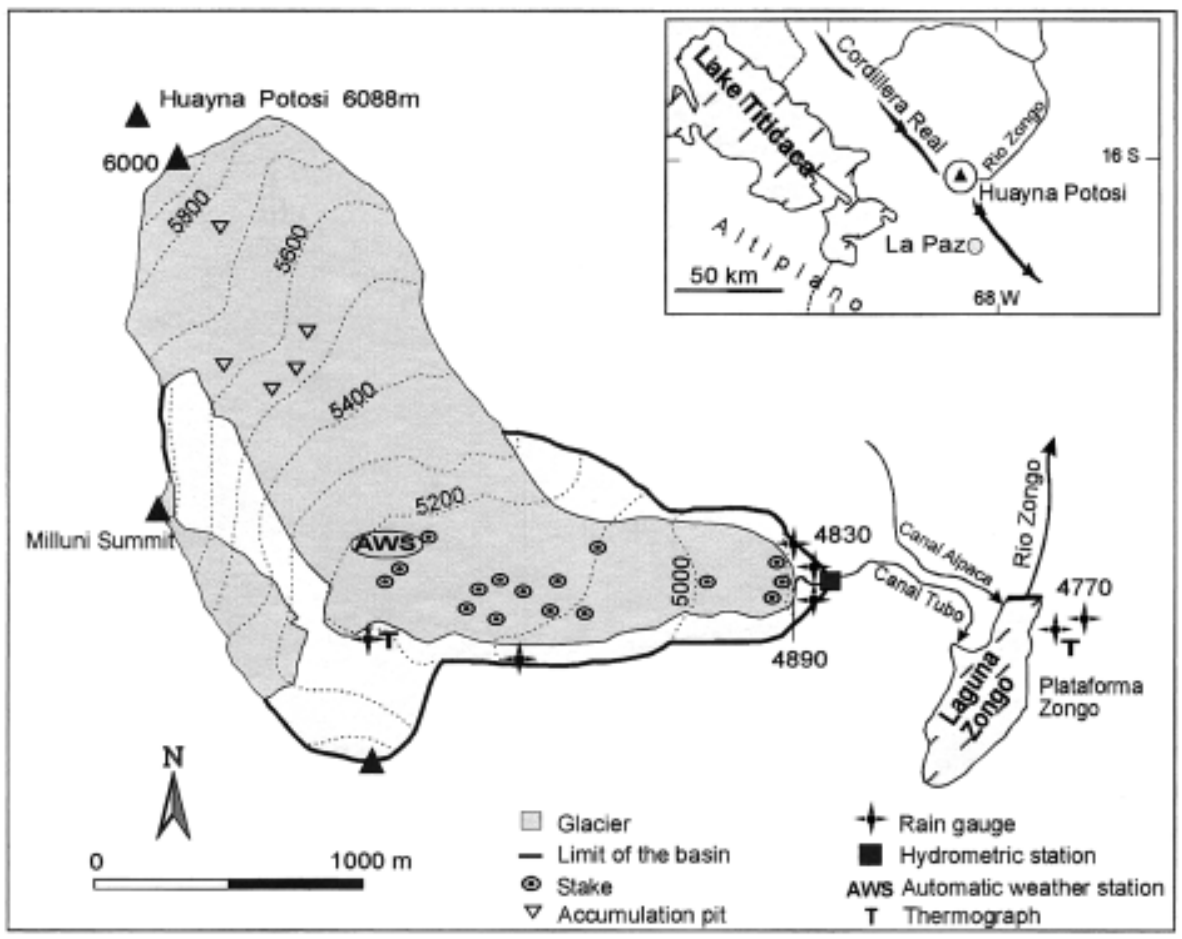

Fig. 1. Glaciar Zongo $\left(2.1 \mathrm{~km}^{2}\right)$ showing location of monitoring equipment.

gauges and a temperature logger were installed in August 1991, and the Campbell AWS has been running since March 1996 on the glacier, at $5150 \mathrm{~m}$ a.s.l. Ventilated dry and wet bulb temperatures and wind speed are recorded at two levels above the surface (roughly 30 and $180 \mathrm{~cm}$ ). Air temperatures, wind speeds and direction, incident shortwave radiation, reflected shortwave radiation, net all-wave radiation, and temperatures at various depths inside the snow/ ice are recorded as half-hourly means over $15 \mathrm{~s}$ time-steps. Dry and wet bulb temperatures are obtained from psychrometers equipped with $\mathrm{Cu}-\mathrm{C}$ st thermocouples and continuously ventilated by a motor whose energy supply comes from a truck battery $(12 \mathrm{~V} / 100 \mathrm{Ah})$, recharged by a $43 \mathrm{~W}$ solar panel. To prevent measurement errors due to radiation, these psychrometers are shielded with two white interlocked cylinders 8 and $12 \mathrm{~cm}$ in diameter, topped by a white $30 \mathrm{~cm}$ diameter disk. Campbell Met One and Young anemometers provide wind speed and direction. A Q-6 Campbell net radiometer $(0.25<\lambda<60 \mu \mathrm{m})$ gives the net all-wave radiation with an accuracy depending on the horizontality of the sensor (from \pm 3 to $\pm 10 \%$ ). Additionally, incident and reflected shortwave radiation are recorded by SP1100 and Li-Cor pyranometers $(0.35<\lambda<1.1 \mu \mathrm{m}$; accuracy $\pm 3 \%)$. In March 1996, most of these sensors were new and adequately calibrated prior to the installation of the AWS on the glacier. In addition to accuracy tests by the manufacturer, intercomparisons of the sensors of the station and with other available sensors (e.g. Q-7 Campbell net radiometer or handle psychrometer) were carried out before their use on the glacier and while they were running at the weather station. The accuracy of the sensors is estimated according to these intercomparisons and the manufacturer's specifications (Table 1). The heights (or depths) of the sensors may vary with ablation or accumulation of snow, but an ultrasound sensor (Campbell UDG01 Ultrasonic Depth Gauge; accuracy $\pm 1 \mathrm{~cm})$ means that the relative surface elevation is known with precision each day.

\section{ENSO, PROGLAGIAL STREAM DISGHARGE AND MASS BALANGE (1991-98)}

A commonly used index of the Southern Oscillation is the normalized sea-level pressure difference between Tahiti and Darwin (Chen, 1982; Philander, 1990). With this Southern Oscillation index (SOI), large negative values correspond to El Niño events, and large positive values to La Niña events (Glantz, 1996). A 5 month moving average of the index is shown in Figure 2, together with the local monthly precipitation, the monthly mass balance in the ablation area between 5030 and $5170 \mathrm{~m}$ a.s.l. and the monthly discharge of the pro-

Table 1. List of different sensors with their specificity, installed on the AWS at $5150 \mathrm{~m}$ a.s.l.

\begin{tabular}{|c|c|c|c|}
\hline Quantity & Sensor type & $\begin{array}{c}\text { Height } \\
\mathrm{cm}\end{array}$ & Accuracy \\
\hline Air temperature $\left({ }^{\circ} \mathrm{C}\right)$ & $\mathrm{Cu}-\mathrm{Cst}$ thermocouples & 30 and 180 & $\pm 0.3^{\circ} \mathrm{C}$ \\
\hline Vapour pressure $(\mathrm{hPa})$ & Wet bulb $\mathrm{Cu}-$ Cst thermocouples & 30 and 180 & $\pm 0.3 \mathrm{hPa}$ \\
\hline Wind speed $\left(\mathrm{m} \mathrm{s}^{-1}\right)$ & Met One Campbell-Campbell 05103-Young & 30 and 180 & $\pm 1.5 \%$ \\
\hline Wind direction $\left(^{\circ}\right)$ & Campbell 05103-Young & 30 and 180 & \pm 3 \\
\hline Incident shortwave radiation $\left(\mathrm{W} \mathrm{m}^{-2}\right)$ & Campbell SP1100 and Li-Cor & 100 & $\pm 3 \%$ \\
\hline Reflected shortwave radiation $\left(\mathrm{W} \mathrm{m}^{-2}\right)$ & Campbell SP1100 and Li-Cor & 100 & $\pm 3 \%$ \\
\hline Net all-wave radiation $\left(\mathrm{W} \mathrm{m}^{-2}\right)$ & Q-6 net radiometer & 100 & $\pm 3 \%$ to $\pm 10 \%$ \\
\hline Snow/ice temperature $\left({ }^{\circ} \mathrm{C}\right)$ & $\mathrm{Cu}-\mathrm{Cst}$ thermocouples & $-20,-30,-50,-70,-100,-150,-270$ & $\pm 0.3^{\circ} \mathrm{C}$ \\
\hline
\end{tabular}



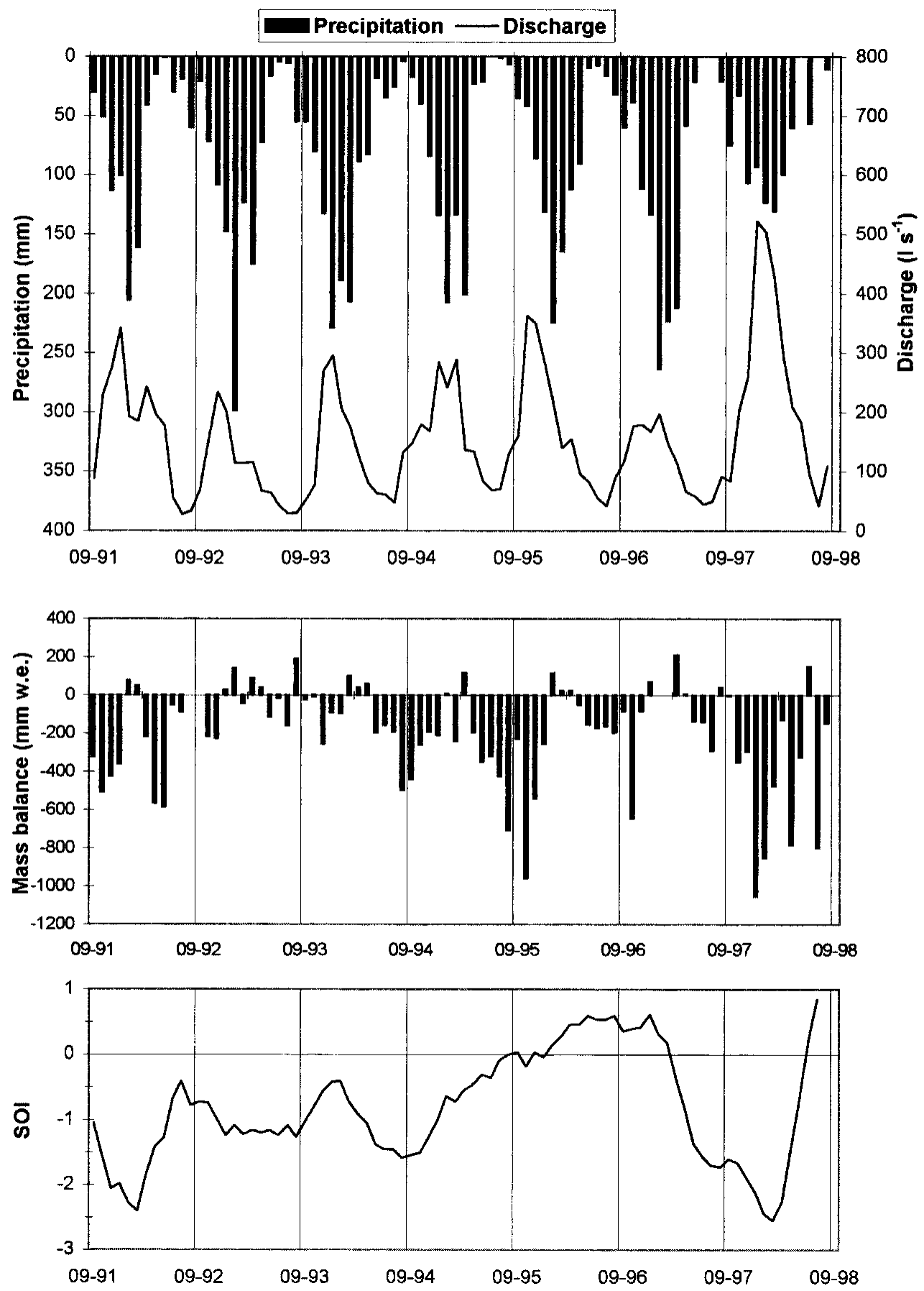

Fig. 2. Monthly means of precipitation recorded at $4770 \mathrm{~m}$ a.s.l., monthly means of the discharge of the proglacial stream recorded instantaneously by a water-level recorder (4830 m a.s.l.) and monthly means of the mass balance in the ablation area between 5030 and $5170 \mathrm{~m}$ a.s.l. obtained from four to ten stakes (depending on the year) for seven hydrological years (September 1991-August 1998). The hydrological year (1 September-31 August) is marked by a wet season (November-March) and a dry season (May-August). During this 7 year period, the SOI mostly exhibits negative values (Trenberth and Hoar, 1996) with two well-marked ENSO warm events in 1991/92 and 1997/98 and a La Niña event in 1996/97.

glacial stream of Glaciar Zongo. In the outer tropics zone, which is characterized by a lack of thermal seasonality but has a hydrological year that is punctuated by one dry and one wet season (Kaser and others, 1996), strong ENSO warm events (1991/92 and 1997/98) result in a precipitation deficit. At Glaciar Zongo, this deficit was about 25\% (Table 2), as already observed on Quelccaya ice cap (southern Peru) (Thompson and others, 1984). ENSO warm events are also accompanied by a strongly negative hydrological balance (Ribstein and others, 1995), as shown by the very high discharge of the proglacial stream (Fig. 2; Table 2). Indeed, during the strong $1997 / 98$ ENSO warm event, annual runoff in the proglacial stream is $63 \%$ higher than the mean runoff of the 1973-98 period. A similar increased runoff had been observed during the previous, weaker, 1991/92 ENSO warm event but it was not as spectacular as in 1997/98.

During the 1991-98 period, dominated by ENSO warm conditions (Trenberth and Hoar, 1996), the net mass balances are contrasted. During the two strong ENSO warm events (1991/92 and 1997/98), the mass deficit at year scale is very high (-900 and $-1960 \mathrm{~mm}$ w.e., respectively) (Table 2). In such a situation, the ELA is high in elevation, and ablation conditions prevail on $60 \%$ of the surface area (Fig. 3). A typical feature of tropical glaciers is their steep vertical budget gradient corresponding to a decrease of at least $1000 \mathrm{~mm}$ w.e. of the local mass balance over a $100 \mathrm{~m}$ vertical drop in altitude 
Table 2. Annual values of precipitation, runoff and mass balance for seven hydrological cycles (1 September-31 August)

\begin{tabular}{|c|c|c|c|c|c|c|c|}
\hline & $\underline{1991 / 92}$ & 1992/93 & $1993 / 94$ & $1994 / 95$ & $1995 / 96$ & $1996 / 97$ & $\underline{1997 / 98}$ \\
\hline Precipitation (mm) & 825 & 1100 & 1145 & 870 & 950 & 1140 & 785 \\
\hline Deviation from mean $(\%)$ & -21 & 5 & 9 & -17 & -9 & 9 & -25 \\
\hline Runoff (mm) & 1790 & 1080 & 1370 & 1680 & 1780 & 1280 & 2570 \\
\hline Deviation from mean $(\%)$ & 13 & -32 & -13 & 6 & 13 & -19 & 63 \\
\hline Mass balance (mm w.e.) & -900 & 520 & -90 & -700 & -670 & 800 & -1960 \\
\hline
\end{tabular}

Notes: The annual depth of runoff is obtained by dividing the mean discharge recorded at the limnimetric station at $4830 \mathrm{~m}$ a.s. 1. by the area of the $3 \mathrm{~km}{ }^{2}$ basin (Ribstein and others, 1995). Precipitation is recorded at $4770 \mathrm{~m}$ a.s.l., about $500 \mathrm{~m}$ from the glacier tongue. Deviations are the deviations from the mean precipitation and mean runoff measured between 1973 and 1998 (mean precipitation $=1046 \mathrm{~mm}$ and mean specific runoff $=1580$ mm). Underlined hydrological years are intense ENSO warm years.

(Francou and others, 1995; Wagnon and others, 1999) (Fig. 4). Thus, a small displacement of the ELA can lead to highly contrasted net mass balances, as during the 1996/97 and the 1997/98 cycles (1996/97: ELA = 5075 m a.s.l.; 1997/98: ELA = 5525 ma.s.l.). On a monthly basis, a comparison of net balance in the ablation area and the SOI shows that the high ablation rates fit well into the ENSO years, such as 1997/98, 1991/92 and 1994/96, and moderate ablation conditions prevail during the 1996/97 La Niña cycle (Fig. 2). But positive mass balances can also occur during periods of negative SOI, as in 1992/93. The relation between the two variables is therefore not always clear.

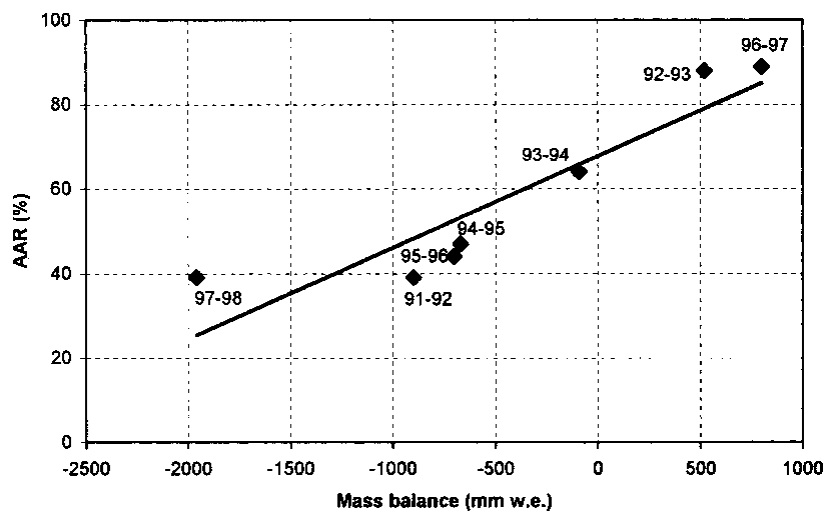

Fig. 3. Accumulation area ratio ( $A A R)$ vs net mass balance on Glaciar Zongo for the 1991-98 period. During the El Niño years negative net mass balance concerns $60 \%$ of the glacier area.

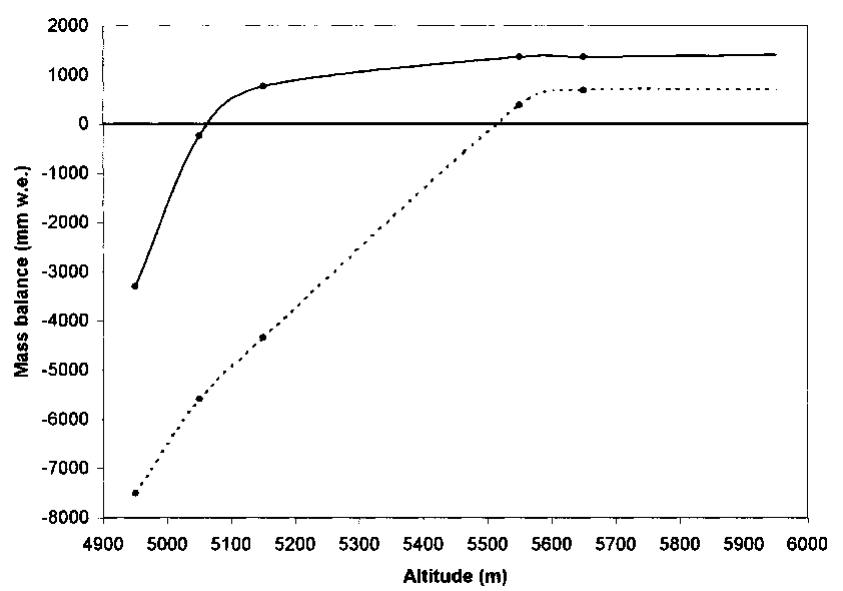

Fig. 4. Annual mass balance vs elevation on Glaciar Zongo during the 1996/97 hydrological year (solid line) and during the 1997/98 year (dashed line). In 1996/97 the vertical massbalance gradient in the ablation area was $3060 \mathrm{~mm}$ w.e. per $100 \mathrm{~m}$. In 1997/98 it was $1310 \mathrm{~mm}$ w.e. per $100 \mathrm{~m}$.

\section{ATMOSPHERIC CONDITIONS OF HYDROLOGICAL YEARS 1996/97 AND 1997/98}

To understand the physical processes responsible for the increased melting observed during strong ENSO warm events resulting in very negative mass balance, we focus on the last two hydrological cycles: 1 September 1996 to 31 August 1997, and 1 September 1997 to 31 August 1998, which are characterized by weak positive and large negative SOI, respectively (Fig. 2). Figure 5 shows the monthly means of various meteorological variables recorded by the AWS located at $5150 \mathrm{~m}$ a.s.l.
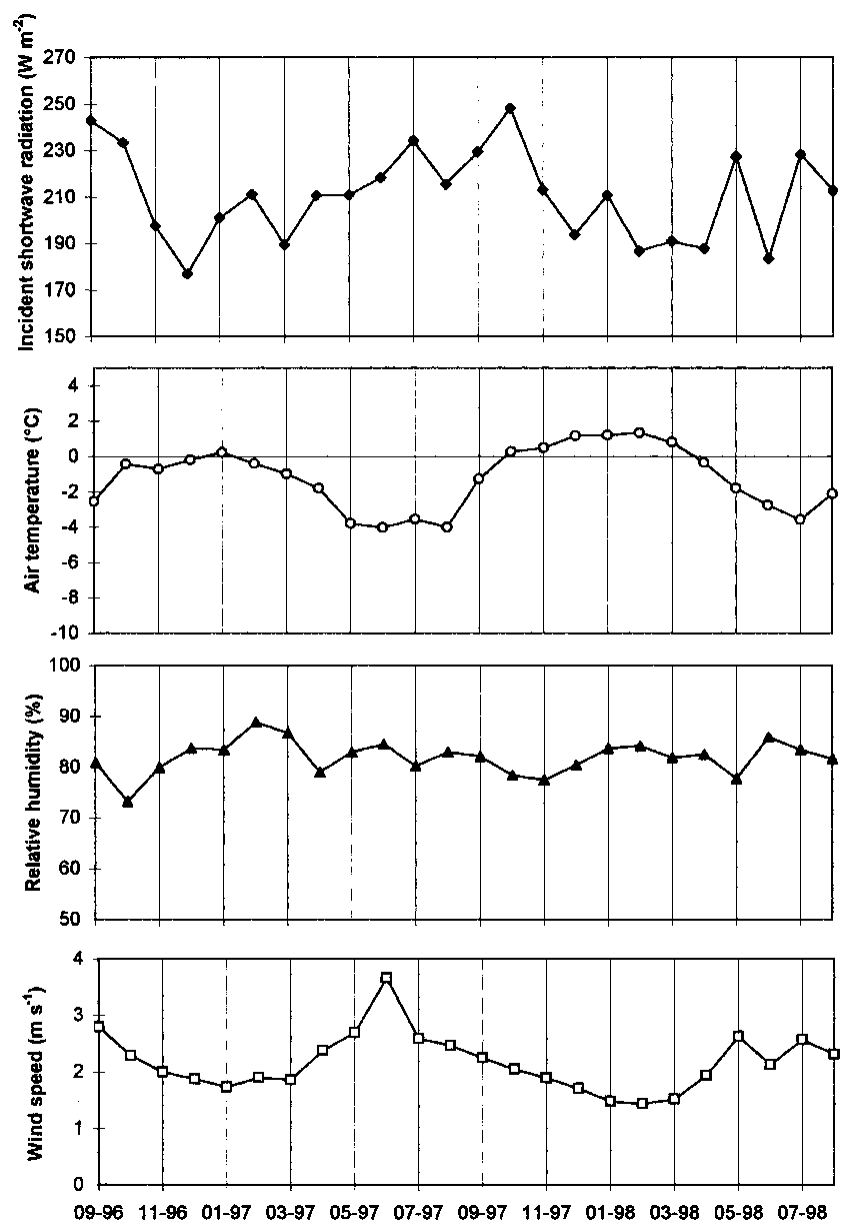

Fig. 5. Monthly means of ventilated incident shortwave radiation, air temperature, relative humidity and wind speed (September 1996-August 1998), recorded by the Campbell AWS, installed at the glacier surface at $5150 \mathrm{~m}$ a.s.l. The only variable showing visible differences from one year to the other is the air temperature, $1.3^{\circ} \mathrm{C}$ higher on average between 1996/ 97 ( La Niña year, annual mean temperature of $-1.8^{\circ} \mathrm{C}$ ) and 1997/98 ( El Niño year, annual mean temperature of $-0.5^{\circ} \mathrm{C}$ ). 
on the glacier surface. Table 3 gives the annual means of these variables. Neither incident solar radiation, relative humidity, nor wind speed shows any significant difference from one year to the other. During the wet season (November-March), the cloudiness is higher and therefore the incident solar radiation is lower. Air temperature for the $1997 / 98$ wet season $\left(+1.0^{\circ} \mathrm{C}\right)$, characterized by a strongly negative SOI, is somewhat higher than the mean air temperature for the period November 1996-March $1997\left(-0.4^{\circ} \mathrm{C}\right)$.

\section{ENERGY-BALANGE STUDY}

A precise surface energy-balance study is necessary to understand how moderate variations of air temperature and precipitation can lead to a sharp increase in the melting of tropical glaciers during ENSO warm events. The method to calculate the annual cycle of the energy balance of Glaciar Zongo has already been described in detail (Wagnon and others, 1999). The local melting $\Delta Q_{\mathrm{M}}$ at $5150 \mathrm{~m}$ a.s.l. is derived from the energy-balance equation for a melting surface:

$$
R+H+\mathrm{LE}+G+P=\Delta Q_{\mathrm{M}},
$$

where $R$ is net all-wave radiation, $H$ is the turbulent sensibleheat flux, LE is the turbulent latent-heat flux, $G$ is the conductive energy flux in the snow or ice, $P$ is the heat supplied by precipitation and $\Delta Q_{\mathrm{M}}$ is the latent-heat storage change due to melting or freezing. Energy fluxes directed towards the surface are defined as positive, and those from the surface as negative. Since this glacier is isothermal at $0^{\circ} \mathrm{C}$ (Francou and others, 1995), the mean daily conductive heat flux into snow or ice $G$ remains zero all the time. Since precipitation is always snow in the vicinity of the equilibrium line and since snowfall intensities are usually weak, $P$ remains insignificant and negligible compared to the other terms of Equation (1).

\section{Net all-wave radiation}

The net all-wave radiation is measured directly on the field site by the AWS.

\section{Turbulent heat fluxes}

The transport of heat and moisture in the surface boundary layer of the atmosphere is dominated by turbulent motions. The turbulent sensible- and latent-heat fluxes can be calculated with the Monin-Obukhov similarity theory. According to this theory, the mean vertical gradients of wind speed $\mathbf{v}=(u, v)$, potential temperature $\theta$ and specific humidity $q$ are related to the corresponding fluxes as:

Table 3. Annual values of air temperature, relative humidity, wind speed, incident shortwave radiation and albedo at 5150 m a.s.l. at the glacier surface (1 September-31 August)

\begin{tabular}{lcc}
\hline & $1996 / 97$ & $1997 / 98$ \\
& & \\
\hline Air temperature $\left({ }^{\circ} \mathrm{C}\right)$ & -1.8 & -0.5 \\
Relative humidity $(\%)$ & 82 & 82 \\
Wind speed $\left(\mathrm{m} \mathrm{s}^{-1}\right)$ & 2.4 & 2 \\
Incident shortwave radiation $\left(\mathrm{W} \mathrm{m}^{-2}\right)$ & 212 & 209 \\
Albedo & 0.75 & 0.58 \\
\hline
\end{tabular}

$$
\begin{aligned}
& \frac{k z}{u^{*}} \frac{\partial u}{\partial z}=\Phi_{\mathrm{m}}\left(\frac{z}{L}\right) \\
& \frac{k z}{\theta^{*}} \frac{\partial \theta}{\partial z}=\Phi_{\mathrm{h}}\left(\frac{z}{L}\right) \\
& \frac{k z}{q^{*}} \frac{\partial q}{\partial z}=\Phi_{\mathrm{v}}\left(\frac{z}{L}\right) .
\end{aligned}
$$

The characteristic scales of velocity, $u^{*}$ (also called the friction velocity), of potential temperature, $\theta^{*}$, and of specific humidity, $q^{*}$, are defined by:

$$
\begin{aligned}
& u^{*}=(\tau / \rho)^{1 / 2}, \\
& \theta^{*}=H /\left(\rho C_{\mathrm{P}} u^{*}\right), \\
& q^{*}=\mathrm{LE} /\left(\rho L_{\mathrm{s}} u^{*}\right),
\end{aligned}
$$

where $\tau$ is the surface stress, $\rho=0.69 \mathrm{~kg} \mathrm{~m}^{-3}$ is the air density at $5150 \mathrm{~m}$ a.s.l. $(540 \mathrm{hPa}), C_{\mathrm{P}}$ is the specific heat capacity for air at constant pressure $\left(C_{\mathrm{P}}=C_{\mathrm{pd}}(1+0.84 q)\right.$ with $C_{\mathrm{pd}}=1005 \mathrm{~J} \mathrm{~kg}^{-1} \mathrm{~K}^{-1}$, the specific heat capacity for dry air at constant pressure), $L_{\mathrm{S}}$ is the latent heat of sublimation of snow or ice $\left(L_{\mathrm{s}}=2.834 \times 10^{6} \mathrm{~J} \mathrm{~kg}^{-1}\right), z$ is the height above the surface and $k$ is the von Kármán constant $(k=0.4)$. The non-dimensional stability functions for momentum $\left(\Phi_{\mathrm{m}}\right)$, for heat $\left(\Phi_{\mathrm{h}}\right)$ and moisture $\left(\Phi_{\mathrm{v}}\right)$ have to be determined empirically and are assumed to depend only on the stability parameter $z / L$, where $L$ is the Monin-Obukhov length:

$$
L=\frac{u^{* 2}}{k\left(\frac{g}{T}\right)\left(\theta^{*}+0.61 q^{*} T\right)} .
$$

$g$ is the acceleration of gravity and $T$ is a reference temperature assumed to be the air temperature near the surface. Once the $\Phi$ functions have been specified from the literature (Brutsaert, 1982; Morris, 1989), Equations (2-4) can be integrated to give equations which relate fluxes to differences in wind speed, temperature and specific humidity between two levels $z_{1}$ and $z_{2}$ (roughly 30 and $180 \mathrm{~cm}$, depending on the snow height):

$$
\begin{aligned}
& u^{*}=k\left(u_{2}-u_{1}\right)\left[\ln \left(z_{2} / z_{1}\right)-\Psi_{\mathrm{m}}\left(z_{2} / L\right)+\Psi_{\mathrm{m}}\left(z_{1} / L\right)\right]^{-1} \\
& \theta^{*}=k\left(\theta_{2}-\theta_{1}\right)\left[\ln \left(z_{2} / z_{1}\right)-\Psi_{\mathrm{h}}\left(z_{2} / L\right)+\Psi_{\mathrm{h}}\left(z_{1} / L\right)\right]^{-1} \\
& q^{*}=k\left(q_{2}-q_{1}\right)\left[\ln \left(z_{2} / z_{1}\right)-\Psi_{\mathrm{v}}\left(z_{2} / L\right)+\Psi_{\mathrm{v}}\left(z_{1} / L\right)\right]^{-1}
\end{aligned}
$$

The $\Psi$ functions $\Psi_{\mathrm{m}}$ for momentum, $\Psi_{\mathrm{h}}$ for heat and $\Psi_{\mathrm{v}}$ for water vapour are the vertically integrated forms of the $\Phi$ functions and they depend on the stability of the surface layer:

Unstable conditions $(z / L<0)$ :

$$
\begin{aligned}
& \Psi_{\mathrm{m}}=2 \ln \left(\frac{1+x}{2}\right)+\ln \left(\frac{1+x^{2}}{2}\right)-2 \arctan (x)+\frac{\pi}{2} \\
& \Psi_{\mathrm{h}}=\Psi_{\mathrm{v}}=2 \ln \left(\frac{1+x^{2}}{2}\right)
\end{aligned}
$$

Stable conditions $(0<z / L<1)$ :

$$
\Psi_{\mathrm{m}}=\Psi_{\mathrm{h}}=\Psi_{\mathrm{v}}=-5 z / L,
$$

Very stable conditions $(z / L>1)$ :

$$
\Psi_{\mathrm{m}}=\Psi_{\mathrm{h}}=\Psi_{\mathrm{v}}=-5[\ln (z / L)+1],
$$

where $x=(1-16 z / L)^{1 / 4}$ (Brutsaert, 1982).

The calculations are performed iteratively: the first estimates of $u^{*}, \theta^{*}$ and $q^{*}$ are obtained from Equations (9-11) assuming first that $z / L=0$ (logarithmic profiles), and the 
results are used to calculate $L$ from Equation (8). According to the sign of $L$, this value of $L$ can be substituted back into Equations (9-11) to improve the estimates of $u^{*}, \theta^{*}$ and $q^{*}$. The scheme usually converges within four iterations, giving values of $H$ and LE from Equations (6-7).

In the Monin-Obukhov theory, the fluxes of momentum, sensible and latent heats are supposed to be constant with height. Therefore, turbulent fluxes calculated between $z_{1}$ and $z_{2}$ are equal to surface turbulent fluxes. Nevertheless, on Glaciar Zongo we observe temperature profile anomalies leading to fluxes variable with height. During the day, a highly stable sub-layer forms near the surface, with a persistent warm layer around $20-30 \mathrm{~cm}$, whereas at night profiles agree more with classical log-linear forms found in stable air (Wagnon and others, 1999). For this reason, at night, while the constant flux layer is well developed over the surface, turbulent fluxes are estimated using the Monin-Obukhov method described above. During the day, as soon as the warm layer appears, the fluxes are estimated using the Monin-Obukhov method between the surface and the first measurement level $z_{1}\left(z_{1} \approx 30 \mathrm{~cm}\right.$, depending on the snow height), i.e. applying the bulk aerodynamic approach with stability correction. During the day, snow is melting at the field site, so the surface temperature is assumed to be $0^{\circ} \mathrm{C}$ and the vapour pressure is assumed equal to the saturation vapour pressure $(6.1 \mathrm{hPa})$. Since during the day the Monin-Obukhov similarity theory must be applied between the surface and $z_{1}$, surface roughness parameters for momentum $z_{0 \mathrm{~m}}$, for temperature $z_{0 \mathrm{~T}}$ and for humidity $z_{0 q}$ must be evaluated (in Equations (9-11), $z_{2}$ is replaced by $z_{1}$, and $z_{1}$ by $z_{0 \mathrm{~m}}$ in Equation (9), by $z_{0 \mathrm{~T}}$ in Equation (10), and by $z_{0 \mathrm{q}}$ in Equation (11)). By definition, $z_{0 \mathrm{~m}}$ is the height where the horizontal component of the wind speed is zero, $u\left(z_{0 \mathrm{~m}}\right)=0$. The three roughness lengths are set equal to each other: $z_{0 \mathrm{~m}}=z_{0 \mathrm{~T}}=z_{0 \mathrm{q}}=z_{0}$. The value of $z_{0}$ is estimated iteratively in order to have the best agreement between calculated latent heat flux and daily sublimation as measured by lysimeters on the field site during selected days. This indirect method to obtain $z_{0}$ based on direct field measurements is not suitable to distinguish $z_{0 \mathrm{~m}}$ from $z_{0 \mathrm{~T}}$ and $z_{0 \mathrm{q}}$ because as many triplets of values as we want might fit the direct measurements. Therefore, keeping a unique value is more logical even if many authors suggest that $z_{0 \mathrm{~T}}$ and $z_{0 \mathrm{q}}$ are 1 or 2 orders of magnitude lower than $z_{0 \mathrm{~m}}$ (e.g. Morris, 1989). The value of $z_{0}$ obtained by this method is therefore a kind of bulk parameter but has the dimension of a roughness length since it is a compilation of the three roughness parameters. From season to season, the "bulk roughness parameter" $z_{0}$ at the weather station is variable, going from a minimum value of $2 \mathrm{~mm}$ on smooth surfaces and recent snow during the wet season to a maximum value of $3 \mathrm{~cm}$ corresponding to rough surfaces of $40 \mathrm{~cm}$ high penitents typical of the middle of the dry season.

\section{RESULTS: ENERGY BALANGE OF HYDROLOGICAL YEARS 1996/97 AND 1997/98}

The results of the energy balance are compared (monthly means of $R, H$ and LE) in Figure 6 and Table 4 between the two contrasted cycles 1996/97 and 1997/98. During the last ENSO year (1997/98), the energy available for melting $\Delta Q_{\mathrm{M}}$ at $5150 \mathrm{~m}$ a.s.l. is much higher than for the preceding La Niña year $\left(46.9 \mathrm{~W} \mathrm{~m}^{-2}\right.$ instead of $3.8 \mathrm{~W} \mathrm{~m}^{-2}$, which corresponds to an annual melted layer of $4400 \mathrm{~mm}$ w.e. in $1997 / 98$ and $400 \mathrm{~mm}$ w.e. in 1996/97 at $5150 \mathrm{~m}$ a.s.l.).

The 1997/98 annual sublimation corresponds to a mass loss of $129 \mathrm{~mm}$ w.e. $\left(\mathrm{LE}=-11.6 \mathrm{~W} \mathrm{~m}^{-2}\right)$ only, whereas in $1996 / 97$ it is as high as $202 \mathrm{~mm}$ w.e. $\left(\mathrm{LE}=-18.1 \mathrm{~W} \mathrm{~m}^{-2}\right)$.

Table 4. Annual values of net all-wave radiation $R$, turbulent sensible-heat flux $H$, turbulent latent-heat flux LE, and the sum of these three terms corresponding to the energy available for melting $\Delta Q_{\mathrm{M}}$ (1 September-31 August)

\begin{tabular}{lrrr}
\hline & $1996 / 97$ & $1997 / 98$ & $\begin{array}{c}\text { Difference } \\
\text { 1997/98-1996/97 }\end{array}$ \\
\hline Net all-wave radiation $\left(\mathrm{W} \mathrm{m}^{-2}\right)$ & 15.8 & 48.7 & 32.9 \\
Sensible-heat flux $\left(\mathrm{W} \mathrm{m}^{-2}\right)$ & 6.1 & 9.8 & 3.7 \\
Latent-heat flux $\left(\mathrm{W} \mathrm{m}^{-2}\right)$ & -18.1 & -11.6 & 6.5 \\
Energy for melting $\left(\mathrm{W} \mathrm{m}^{-2}\right)$ & 3.8 & 46.9 & 43.1 \\
\end{tabular}

\section{QR $\mathrm{RH}$ 口LE}

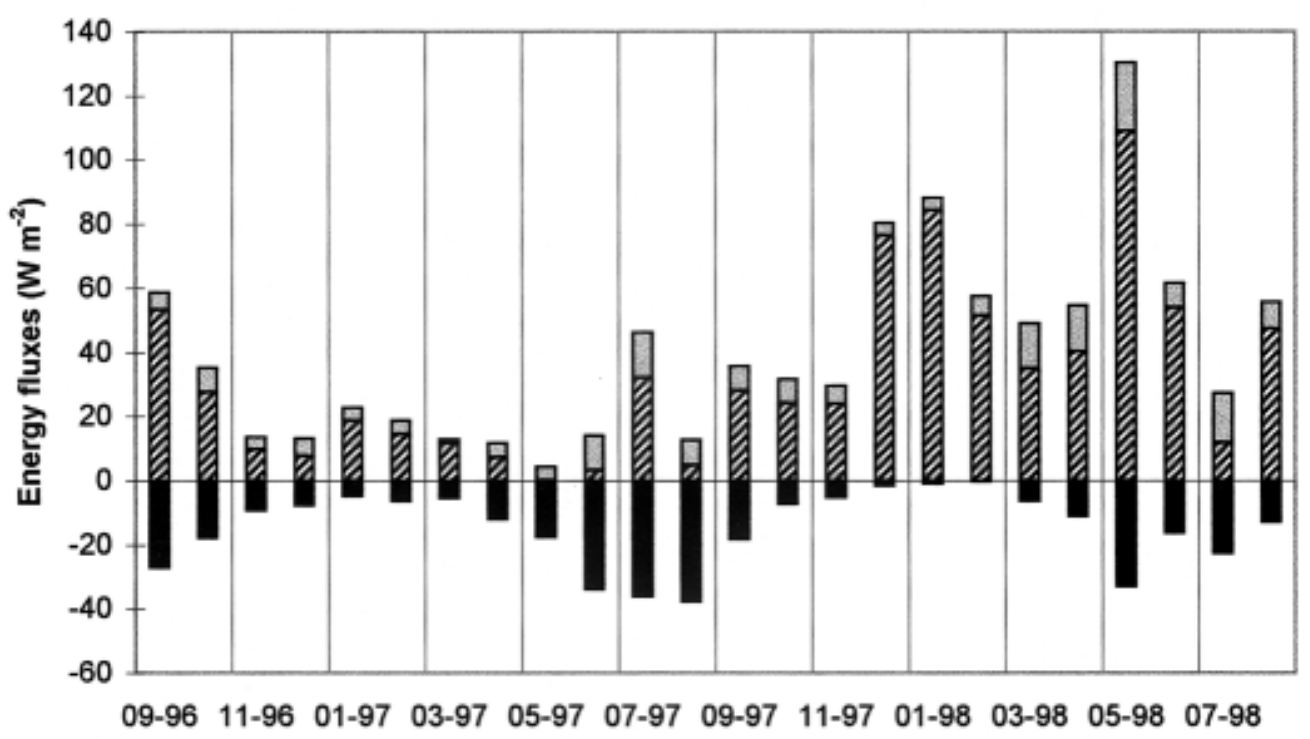

Fig. 6. Monthly means of the different terms of the energy balance at 5150 m a.s.l., September 1996-August 1998. R is the net allwave radiation, $H$ and $L E$ are the sensible-and latent-heat fluxes, respectively. The algebraic sum of these fluxes gives the energy available for melting (or refreezing if negative) at the glacier surface, at $5150 \mathrm{~m}$ a.s.l. 
The sensible-heat flux $H$ is slightly higher in 1997/98 than in 1996/97 because of the air-temperature increase leading to stronger vertical gradients of air temperature above the melting surface at $0^{\circ} \mathrm{C}$. Actually, the turbulent components of the energy balance increase the amount of energy available for melting, but to a much smaller extent than the net radiation $R$ (Table 4). Thus, net radiation is clearly the main flux explaining the very high rates of melting at the glacier surface at $5150 \mathrm{~m}$ a.s.l. Moreover, $R$ is mainly controlled by the surface shortwave albedo (Wagnon and others, 1999). Figure 7 shows the great difference in the monthly means of albedo at the AWS (5150 m a.s.l.) between the two hydrological cycles (respective annual means are 0.75 and 0.58 for 1996/97 and 1997/98; Table 3), in comparison with both modelled and measured ablation. The highest values of ablation are clearly related to the lowest values of albedo. As an example, the surface of the ablation area in May 1998 remained exceptionally dirty, with an albedo of 0.2 leading to the highest monthly ablation rate ever recorded at $5150 \mathrm{~m}$ a.s.l. The sharp decrease of albedo between these two cycles is the key mechanism explaining the strong melting of tropical glaciers during an ENSO warm event.

\section{DISGUSSION AND GONGLUSION}

In 1996/97, the ELA is $5075 \mathrm{~m}$ a.s.l. and the AWS is mostly subject to accumulation conditions with a surface of high-albedo snow. During the following ENSO year, the ELA is $450 \mathrm{~m}$ higher in altitude. Therefore, the AWS mostly remains in ablation conditions, with a dirty low-albedo surface of bare ice.

The precipitation deficit of the 1997/98 ENSO event thus has dire consequences for the mass balance of the glacier. First, this deficit reduces the snow accumulation on the whole glacier. Second, the wet-season snow cover of the glacier is thinner and disappears more rapidly, especially since air temperature is greater and sublimation smaller than usual. Reduced sublimation saves energy for melting, a much more efficient ablation process. Low-albedo bare ice is then directly exposed to the surface for a longer period of the year, and also at higher altitude. Therefore the absorption of shortwave radiation is greatly increased, leading to high rates of melting. This albedo effect is more efficient as it occurs during the wet season, when strong ablation conditions prevail on the glacier surface, with maximum air temperature and minimum sublimation because of low vertical gradients of vapour pressure.

In conclusion, the high-albedo snow cover deposited during the wet season acts as a protective blanket against solar radiation for the glacier. If, for some reason such as a precipitation decrease coupled with a temperature increase of an ENSO warm event, this blanket melts more rapidly than usual, leaving larger areas of low-albedo surfaces, the glacier exhibits large negative mass and hydrological balances.

The precipitation deficit related to the 1997/98 ENSO warm event, worsened by the temperature increase and the sublimation decrease, strongly influences the albedo of outer tropics glaciers, leading to very negative mass balances. Although the general public as well as some meteorologists and glaciologists nurture the fantasy, "El Niño-warm conditions-glacier melting", we actually experience a different chain of causalities: El Niño-precipitation deficit-albedo decrease$^{-}$-glacier melting. Nevertheless, the effect of ENSO warm events on the tropical climate, discussed here, is superimposed on the effect of the global warming reported in the literature (Hense and others, 1988; Graham, 1995; Diaz and Graham, 1996; Trenberth and Hoar, 1996). Tropical glaciers have been retreating rapidly for some decades because of a combination of both effects, global warming and ENSO warm events.

\section{AGKNOWLEDGEMENTS}

The glaciological programme is supported by l'Institut de Recherche pour le Développement (ex-ORSTOM). The authors are grateful for the assistance received from Instituto de Hidraulica e Hídrologia, Universidad Mayor de San Andrés, La Paz, and from Laboratoire de Glaciologie et Géophysique de l'Environnement, Grenoble. We thank J.

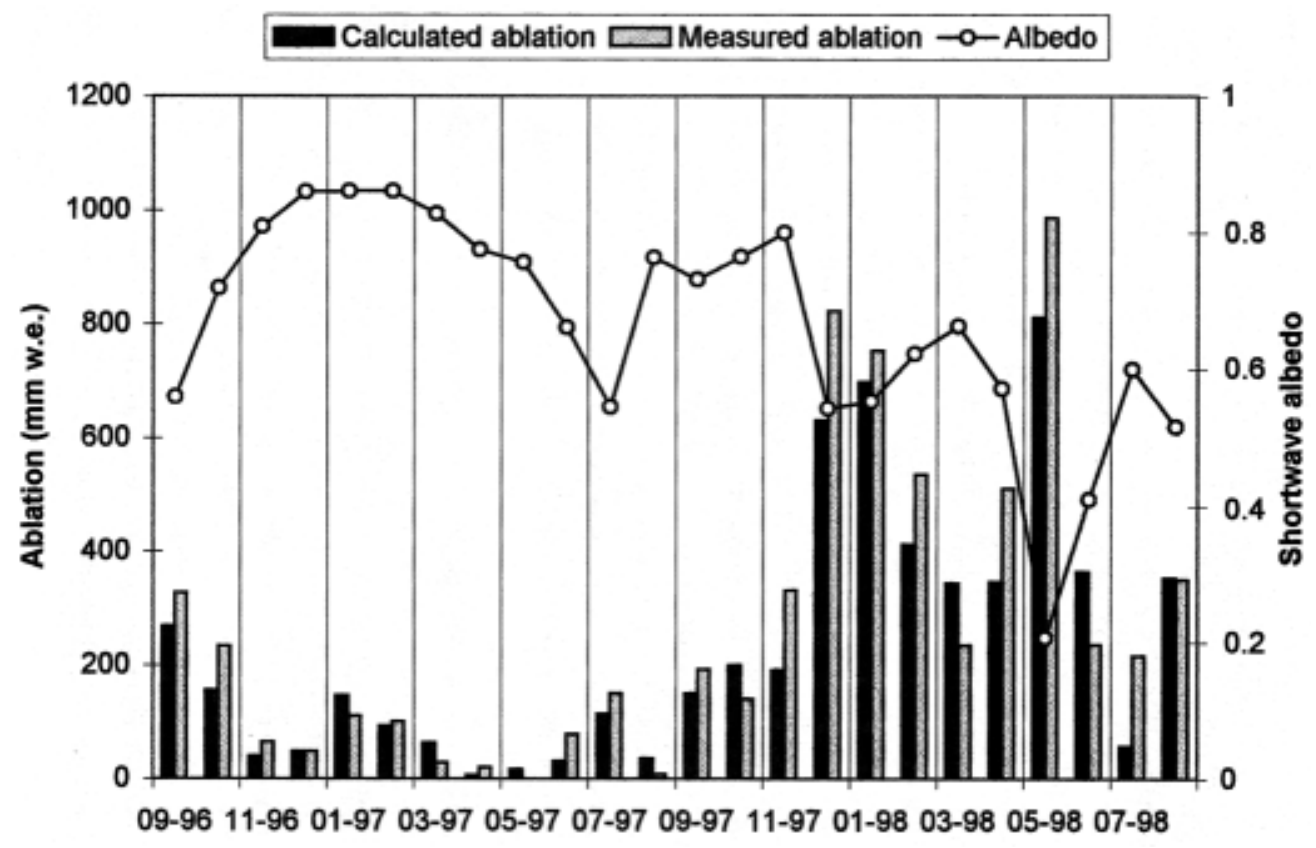

Fig. 7. Monthly measured and calculated ablation and monthly means of shortwave albedo, at 5150 m a.s.l., September 1996August 1998. The measured ablation is deduced from stake and precipitation measurements. The calculated ablation is the sum of melting and sublimation derived from the energy-balance equation. 
Kohler, S. Hastenrath and M. van den Broeke for reviewing the manuscript. The participation of F. Quispe (Compañía Boliviana de Energía Eléctrica) in the mass-balance measurements was much appreciated.

\section{REFERENGES}

Brutsaert, W. H. 1982. Evaporation into the atmosphere. Dordrecht, D. Reidel. Kluwer Academic Publishers.

Chen,W.Y. 1982. Assessment of Southern Oscillation sea-level pressure indices. Mon. Weather Rev., 100, 800-807.

Diaz, H. F. and N. E. Graham. 1996. Recent changes in tropical freezing heights and the role of sea surface temperature. Nature, 383 (6596), 152-155.

Francou, B., P. Ribstein, R. Saravia and E. Tiriau. 1995. Monthly balance and water discharge of an inter-tropical glacier: Zongo Glacier, Cordillera Real, Bolivia, $16^{\circ}$ S. f. Glaciol., 41 (137), 61-67.

Glantz, M. H. 1996. Currents of change: El Niño's impact on climate and society. Cambridge, Cambridge University Press.

Graham, N. E. 1995. Simulation of recent global temperature trends. Science, 267 (5198), 666-671.

Hastenrath, S. and A. Ames. 1995. Diagnosing the imbalance of Yanamarey Glacier in the Cordillera Blanca of Peru. F. Geophys. Res., 100(D3), 5105-5112.

Hastenrath, S. and P. D. Kruss. 1992. The dramatic retreat of Mount Kenya' glaciers between 1963 and 1987: greenhouse forcing. Ann. Glaciol., 16, 127-133.

Hense, A., P. Krahe and H. Flohn. 1988. Recent fluctuations of tropospheric temperature and water vapor content in the tropics. Meteorol. Atmos. Phys., $38(4), 215-227$.

Hodge, S. M., D. G. Trabant, R. M. Krimmel, T. A. Heinrichs, R. S. March and E. G. Josberger. 1998. Climate variations and changes in mass of three glaciers in western North America. F. Climate, 11 (9), 2161-2179.

Kaser, G., S. Hastenrath and A. Ames. 1996. Mass balance profiles on tropical glaciers. Z. Gletscherkd. Glazialgeol., 32, Part 2, 75-81.

Kuhn, M. 1981. Climate and glaciers. International Association of Hydrological
Sciences Publication 131 (Symposium at Canberra 1979-Sea Level, Ice and Climatic Change), 3-20.

Morris, E. M. 1989. Turbulent transfer over snow and ice. F. Hydrol., 105(3-4), 205-223.

Oerlemans, J. 1994. Quantifying global warming from the retreat of glaciers. Science, 264(5156), 243-245.

Oerlemans, J. and J. P. F. Fortuin. 1992. Sensitivity of glaciers and small ice caps to greenhouse warming. Science, 258(5079), 115-117.

Oerlemans, J. and 10 others. 1998. Modelling the response of glaciers to climate warming. Climate Dyn., 14(4), 267-274.

Philander, S. G. 1990. El Niño, La Niña, and the Southern Oscillation. San Diego, CA, Academic Press.

Ribstein, P., E. Tiriau, B. Francou and R. Saravia. 1995. Tropical climate and glacier hydrology: a case study in Bolivia. f. Hydrol., 165(1-4), 221-234.

Thompson, L. G., E. Mosley-Thompson and B. M. Arnao. 1984. Major El Niño/Southern Oscillation events recorded in the stratigraphy of the tropical Quelccaya Ice Cap. Science, 226(4670), 50-52.

Thompson, L. G. and 7 others. 1995. Late glacial stage and Holocene tropical ice core records from Huascarán, Peru. Science, 269(5220), 46-50.

Thompson, L. G. and 11 others. 1998. A 25,000-year tropical climate history from Bolivian ice cores. Science, 282 (5395), 1858-1864.

Trenberth, K. E. and T. J. Hoar. 1996. The 1990-1995 El Niño-Southern Oscillation event: longest on record. Geophys. Res. Lett., 23(1), 57-60.

Vuille, M. 1999. Atmospheric circulation over the Bolivian Altiplano during dry and wet periods and extreme phases of the Southern Oscillation. Int. f. Climatol., 19, 1579-1600.

Vuille, M., D. R. Hardy, C. Braun, F. Keimig and R. S. Bradley. 1998. Atmospheric circulation anomalies associated with 1996/1997 summer precipitation events on Sajama Ice Cap, Bolivia. 7. Geophys. Res., 103, 11,191-11,204.

Wagnon, P., P. Ribstein, B. Francou and B. Pouyaud. 1999. Annual cycle of the energy balance of Zongo Glacier, Cordillera Real, Bolivia. 7. Geophys. Res., 104(D4), 3907-3923.

MS received 18 October 1999 and accepted in revised form 16 October 2000 